\title{
Przemysław OSIEWICZ
}

Uniwersytet im. Adama Mickiewicza, Poznań

\section{The Comparison of the Finnish Security Policy in 1990 and $2002^{1}$}

\section{Preface}

$\mathrm{T}$ he main aim of this essay is to compare the Finnish security policy in two moments, namely in 1990 and 2002. This would be based on comparison of eight factors. These factors concern Finland's attitude towards the EU, NATO, peace - keeping operations, the Soviet Union/Russia, the Nordic cooperation on security issues, the Baltic States, neutrality and nonalignment. Changes are not described in details. Historical facts' function is to support arguments concerning change or lack of change, but focus is only on outcomes of the Finnish security policy. I will try to prove that Finland faced more changes within these factors and only some remained unchanged, giving some empirical arguments supporting that.

How is security defined nowadays? There is no doubt that security policy exists within frame of foreign policy. "The most fundamental source of foreign policy objectives is perhaps the universally shared desire to insure the survival and territorial integrity of the community and state. Military security against invasion or bombardment is the minimum objective of every state's foreign policy"2. Although the meaning of the term 'security' has become extremely extended, I will base on a narrow definition. I regard national security policy as an official governmental policy, which aim is to protect country from any kind of military danger. Such assumption narrows this subject to analysis of national defensive policies, countries' participation in international governmental organizations or international security system by and large.

1 Niniejszy artykuł został napisany podczas pobytu stypendialnego Autora w Szwecji (Södertörns Högskola, Sztokholm).

2 K. R. Legg, J. F. Morrison, The formulation of foreign policy objectives, from: Perspectives on World Politics, R. Little, M. Smith (ed.), Routledge, London-New York 1996, p. 62. 
Since the oldest times countries have tried to make certain that their territories are safe, free from any kind of danger. This security is priceless; it provides necessary conditions for future development. At the very beginning of the modern states' history they were trying to strengthen their positions and weaken potentials of their neighbors. States were self-interested and self-confident. They fought with one another trying to get as much as possible. When lords of kingdoms realized that 'two' meant more than 'one', they started creating unions. Such unions consisted in most cases of two neighbouring countries, e.g. Polish - Lithuanian union from 1386. That was the first step towards establishing the modern international security system in Europe. Then alliances were being created and hundreds of wars were ruining countries across the whole continent.

The conquests of Napoleon Bonaparte awoke diplomats to search for security in balance of power between European countries. The treaty of Vienna from 1815 established such system, which covered almost all countries. As among individuals one always tries to be stronger than others. The same phenomenon appeared in Europe and balance of power was in danger all the time. The sudden death of that system came with the beginning of the First World War in 1914. As the result, after the end of war, the League of Nations was established. Its main aim was to assure safety among European countries through cooperation and peaceful solution of disputes. Unfortunately, it was still not enough to ensure peace and safety. The Second World War broke out and its effects showed whole deficiency of the existing security system. The 'new era' of international security policy began after the war. The bipolar rivalry between the United States and the Soviet Union divided most of countries. Some of them joined the Western bloc controlled by Americans, while others joined the Eastern bloc controlled by Russians. There were also countries, which remained neutral or at least followed the policy of neutrality. Finland was among them. It is another way of providing security. However, the security system develops rather fast and this causes changes in geopolitical environment. Finland faced such a big change in 1990. It could be interesting to analyse how its security policy was adjusted to new conditions, possibilities and requirements. The comparison between the Finnish position in 1990 and the position in 2003 would be useful in such case. It concerns the most important factors such as membership in international organizations, namely NATO and the EU, participation in peacekeeping, attitude towards the Soviet Union / Russia, the Nordic region and the Baltic States. The his- 
torical background has to be described in order to formulate the position from 1990 and then compare it with the position from 2003.

\section{Historical background of the Finnish security policy and its position in 1990}

Finland experienced both Swedish and Russian dominance. From 1809 until 1917 the Finnish territory enjoyed far - reaching autonomy under Russia, but it was still very far from expectations of Finns. The First World War, loses of the Russian army and Russian revolution created ideal conditions for recovery of independence. Finnish independence was established in declaration from 6 December 1917. It was based on cooperation with Germans who were to protect liberated country.

"This policy collapsed with the capitulation of Germany in November 1918. By that time Finland had become compromised in Western eyes, and a complete about - turn in Finnish policy was necessary. The German King - elect abdicated in December 1918 before setting foot on Finnish soil. The pro - German political leaders stood aside"3. In 1919 Finland was recognized by the Allies, namely the United States, the United Kingdom and France. The Tartu Treaty, in which the Russian government recognized independent Finland, was signed in 1920. In 1921 the League of Nations gave Aland Islands to Finland. It prevented both Finland and Sweden from possible war. The islands were demilitarized and neutralized. At that time country was free of foreign political commitments.

In the 1930's Finland started searching for guarantees of its security. Germany became powerful. On the other hand, the government intended to maintain the policy of neutrality. The first step was a non - aggression treaty with the Soviet Union in 1932. "Then in December 1935, the Finnish Parliament unanimously approved a Government resolution declaring Finland's adherence to Scandinavian neutrality. The neutrality of Finland, it was stated, could best be preserved in association with the other Scandinavian nations whose loyalty to the concept of neutrality was universally acknowledge"4 . However, Finland's geopolitical position was in danger. Soon it became clear that it will have to face either German or Soviet inva-

3 M. Jakobson, Finnish Neutrality. A Study of Finnish Foreign Policy since the Second World War, Frederick A. Praeger Publishers, New York 1968, p. 5.

4 M. Jakobson, above, p. 7. 
sion. Germans saw Finland as possible military base for the aggression against the Soviet Union, while Soviets saw it as a defensive line of Leningrad.

Russian threatened Finland and demanded a right to build a military base close to Helsinki. Finns could not agree on that. On 28 November 1939 the Soviet government canceled the non - aggression treaty from 1932. Two days later Soviet aircraft bombed Helsinki and troops crossed the border. Until Christmas Finnish troops managed to stop the Red Army. The West began being interested in Finland's situation. Nevertheless, Finland had to sign a peace treaty on Soviet conditions in Moscow on 7 March 1940.

Finns were still in danger of Soviet occupation and therefore their government sought support in Germany. As the result, they agreed on a transit of German troops through Finland to Norway. When Hitler invaded the Soviet Union on 22 June 1941, Finns tried to maintain neutrality, but it was not possible any longer. Three days later Soviet aircraft bombed military objects in Finland and the Finnish government declared war on the Soviet Union. They did not intend to become allies with Germany, but they were seen as such in the West. Great Britain declared war on Finland in December 1941. After Germany's defeat in the battle of Stalingrad, Finns began looking for support from the West. They were interested in Swedish mediation in the conflict with the Soviet Union. But no agreement was signed and Soviet divisions attacked Finland in June 1944. It has to be emphasized that Finns managed to stop them once again. Most of Soviet troops were required for the race to Berlin and this fact created good conditions for signing a peace treaty. Finland broke off relations with Germany. On 19 September 1944 the Armistice Agreement was signed. Soon after that Finns fought with Germans in the north and forced them into Norway.

Finland was not conquered and managed to maintain continuation of her political institutions. On the basis of the Treaty of Paris from 1947 "all German assets in Finland were transferred to the Soviet Union. No compensation was provided for Finnish assets in Germany or for the destruction wrought by the Germans in Finland during the Finnish - German war. Also Finland assumed responsibility for the surrender of or compensation for property belonging to nationals of the United Nations"s.

5 J. H. Wuorinen, A History of Finland, Columbia University Press, New York-London 1965 , p. 380. 
In February 1948 the Soviet Union tried to sign a defense treaty with Finland. Stalin tried to press the Finnish government for cooperation. President Juho Kusti Paasikivi had a very difficult task. On the one hand, he had to show that Finland followed democratic procedures, e.g. consultation with the members of the Parliament who were generally against. On the other hand, he did not want to strain relations with the Soviet Union. Therefore Finns extended negotiations in order to get a satisfactory outcome. The Treaty of Friendship and Mutual Cooperation was signed finally on 6 April 1948. It obliged Finland to defend its territory with all available forces in case of aggression. That was to protect Leningrad from possible attack from the west. The Treaty was signed for ten years. In 1955 Paasakivi received an exchange offer from Moscow. The Soviets offered Finland the navy base on the Porkkala peninsula back if Finland extended that treaty for another twenty years. As a matter of fact, it was a great opportunity for Finns and they took advantage of it. "The elimination of the Soviet base not only reflected a fundamental improvement in Soviet Finnish relations but also transformed Finland's international position. There was an obvious parallel between Soviet actions on Austria and Finland in 1955. In the case of Finland the Soviet withdrawal from Porkkala opened the way to international recognition of Finnish neutrality. So long as the Finnish government could not claim full control over its territory it could not reasonably ask others to respect its neutrality in the event of war" 6 .

Finns did not regard NATO as a threat, although it was not seen as a friendly alliance. Every tension between the United States and the Soviet Union could end up with a military conflict. In that case Finland would have to follow the Soviet policy. Finland was not obliged to support the Soviet army, but Soviets had right to enter the Finnish territory in case of any military danger. There is no doubt that NATO would have attacked Finland, more precisely Soviet troops located there, in such circumstances. NATO considered Finland as a neutral state, however, western strategists recognized it as a part of the Soviet zone if any tension occurred.

Any membership of Finland in the EEC was not possible due to its neutrality. Finland concluded, "albeit after an arduous domestic debate, an

6 M. Jakobson, Finnish Neutrality. A study of Finnish Foreign Policy since the Second World War, Frederick A. Praeger Publishers, New York 1968, p. 47. 
agreement on free trade with the EEC eleven years later. Full membership of the European Community was not seriously proposed by anybody as it was considered to be concomitant with the end of Finnish neutrality. Until the 1990's European integration was perceived only from this perspective, namely by binding its meaning to the bipolar system of power in Europe and to Finnish neutrality as a part of it" ${ }^{\text {"7 }}$. However, one has to remember that before the European Union was established security issues had not been included within agenda of European integration. The coordination of security policies took place in a separate organization - the Western European Union.

Finland was a part of the so-called 'Nordic Balance'. This term was informal, given by scholars describing security environment in Scandinavia. The Nordic Balance consisted of Norway as a member state of NATO, Sweden as a neutral country and Finland as a state dependent on the Soviet Union. Any kind of cooperation between these three countries was seriously limited. The Nordic Council was established in 1953. "The Soviet Union was overtly suspicious of this new Nordic arrangement, which it considered might become another anti - Russian bloc. To avoid provoking further Soviet reactions, and as a Nordic compromise, the subjects of foreign and security policy were informally banned from the Council's work. In the more auspicious international atmosphere of 1956, Finland finally joined the Nordic Council, but the ban on debating foreign and security policy continued until 1990" 8 .

Finland was taking part in peace - keeping operations organized by the United Nations. It happened for the first time in 1956. Moreover, Finns became soon one of the leading contributors in the world. It can be seen as activity at the global level of security.

The policy of neutrality was being developed in the 1960's. Finland's position at the international arena seemed to be very comfortable and profitable. Neutrality was the answer to all difficult choices between the East and the West. Both the United States and the Soviet Union recognized Finns as their reliable partners in Northern Europe. Nevertheless, the Soviets tried to put pressure on the Finnish government all the time. Moscow

7 T. Tiilikainen, Finland in the EU, from: B. Huldt, T. Tiilikainen, T. Vaahtoranta, A. Helkama - Rågård, Finnish and Swedish Security. Comparing National Policies, Swedish National Defense College/Programme on the Northern Dimension of the CFSP/the Finnish Institute of Foreign Affairs, Helsinki-Stockholm 2001, p. 61.

${ }^{8}$ O. F. Knudsen, Cooperative Security in the Baltic Sea Region, Institute for Security Studies of Western European Union, Paris 1998, p. 31. 
was against the Finnish free trade agreement with the European Community in 1972-1973. Moreover, Soviets proposed even common maneuvers between both armies. Bilateral relations were stabilized in 1980's. Mikhail Gorbachov visited Helsinki in October 1989. "The Soviet Union unreservedly recognized Finnish neutrality. A compromise formula on the definition of Finnish foreign policy was no longer attempted and the traditional joint communiqué method was abandoned. In the so - called Helsinki Declaration, the Finns put forward their own definition: Finland, a neutral Nordic country not possessing nuclear weapons and being active participant in the United Nations and in the process of the Conference on Security and Co - operation in Europe..." . The fall of the Soviet Union and termination of the Warsaw Pact in 1991 changed geopolitical position of Finland and undermined sense of the neutrality's retention.

The position of the Finnish security policy in 1990 (summary):

- Neutrality,

- Nonalignment (since 1986 according to some scholars),

- Closer relations with the Soviet Union - common treaty,

- No cooperation with NATO,

- Support for UN-led peace - keeping operations,

- No cooperation with the EC on security issues,

- No cooperation with other Scandinavian countries on security issues,

- No attitude towards the Baltic States - they were parts of the Soviet Union.

\section{After the Cold War - The Finnish security policy between 1990 and 2002}

The outcome of parliamentary elections in Poland and the first non communist government meant the beginning of big geopolitical changes in Europe. The Eastern bloc had been collapsing until the Soviet Union was finally terminated in 1991. Also the Warsaw Pact disappeared and Finland had a freer hand in international relations. However, those changes meant also a necessity of changes within the Finnish security policy. "In terms of agenda setting, the end of the Cold War provided a paradigmatic policy window that suddenly removed the threat of large scale war in Europe. This opened up for major transformations of security policy.

9 P. Lipponen, Finnish Neutrality and EC Membership, from: Neutral States and the European Community, S. Harden ed., Brassey's, London 1994, p. 85. 
Governments and security advisors went looking for new problems to put on their suddenly empty threat agendas. This opened the window for ideas already floating around in the policy community, such as 'widened security', 'common security', 'security community' and 'cooperative security",

First of all, Finland had to regulate its bilateral relations with the Soviet Union (then Russia) and set new rules. Both sides began working on a new treaty which was to displace the old FCMA Treaty. Negotiations were tough and based on unilateral movements of Finland. The unsure political situation in Russia made it easier for the Finnish government. The new treaty was signed in Helsinki on 20 January 1992 and "generally conforms to bilateral agreements made between EC countries and the Soviet Union or Russia during the last few years. It is based on recognition of the UN Charter and CSCE principles. There are no clauses on military co-operation. Mutual security guarantees are given in Article 4: the parties to the treaty will not use and shall not allow the use of their territories for a military attack against the other party. According to Article 5, should a threat to international peace and security of either party arise, Finland and Russia will, if needed, consult each other about the use of means offered by the United Nations or the CSCE to solve the conflict" ". The Finnish security policy based on non - alignment and self - dependent strong defense.

However, the biggest changes within the Finnish security policy were still to come. The idea of joining the EC (then the EU) brought them in agenda of the Finnish politics. In March 1992 Finland sent its application form concerning future membership in the European Community. The background of this movement can be seen both as an attempt to take part in economic benefits and a step towards creating so called Northern Dimension in EC policy. Negotiations began in 1993. Issues related with the security policy played important role. Finland did not intend to end up with its neutrality and was not interested in deepening of political cooperation concerning security within the EC. On the other hand, maintaining of neutrality became rather hard task. Once Finland joined the EC, it was

10 J. Erikson, Explaining Security Agenda Setting: Beyond the Domestic Realm, from: O. Knudsen ed., Cooperation or Competition? A Juxtaposition of Research Problems Regarding Security in the Baltic Sea Region, Södertörns Högskola, Huddinge 2002, p. 88.

11 P. Lipponen, Finnish Neutrality and EC Membership, from: Neutral States and the European Community, S. Harden ed., Brassey's, London 1994, p. 90-91. 
strongly connected with other member countries and their external problems became also Finnish problems.

The first influence on the Finnish security policy after joining the EU in 1995 Finland joined the European Union as a neutral country, but it was certain that its security policy had to be modified. One could imagine that if any other member state of the EU was attacked, Finland would support it also in military way. Such event could endanger Finnish security and have strong influence on its stability and economy. Although Finland is not obliged to offer any kind of military assistance to attacked member state, it would probably defend its interests in this way. The issue had not existed within the Finnish security policy before Finland joined the EU.

The second influence - EU membership enabled Finland to reduce bilateral military relations with Russia as much as possible. Nowadays the Finnish policy towards the eastern neighbour is based on EU - Russia relationship and synchronized with it. Finns have got strong support from other countries and it strengthens their position. If there was any problem between Finland and Russia on security issues, Moscow would have to deal with the European Union as a whole, not only with the Finnish government.

The third influence - within the EU "Finland, together with Sweden, sponsored expanding the scope of the Common Foreign and Security Policy (CFSP) as provided in the Amsterdam Treaty by adding crisis management, humanitarian and rescue tasks, and peacekeeping measures, the so-called Petersberg Tasks, to the EU's competence"12. Finland takes active part in works of the Political and Security Committee which addresses the Union's common foreign and security policy. General Gustav Hägglund, representing Finland in the Military Committee, became its first chairman.

The fourth influence - cooperation in military crisis management plays very important role. "Finland is taking active part in the creation of the EU's military crisis management capability. Finland's own national readiness has taken account of the EU's aim of achieving military capability by the year 2003, which was decided by the Helsinki European Council in 1999. [...] In establishing its crisis management capability, the EU aims to rely on the support of NATO. The aim is to agree with NATO that the EU

12 R. Rinehart, Finland's European Vocation, from: Scandinavian Studies. The Scandinavian Way to Europe, vol. 74, No. 3, Fall 2002. 
may, if necessary, have access to NATO's command and control systems and other military resources for the purposes of EU - led crisis operations. Finland intends to participate in work carried out by NATO"13. Although Finland is not a member of NATO, it cooperates with this organization through the Partnership for Peace program. PfP was set up in 1994. "It allows the Alliance's Cooperation Partners to take part in security cooperation programs with NATO, including military exercises and civil emergency operations" ${ }^{\prime 14}$. So-called the third phase of the Planning and Review (2000-2006) assumes the deepening of cooperation concerning crisis management. As mentioned above, Finnish soldiers took active part in NATO - led operations in Bosnia and Kosovo.

Besides membership in PfP, Finland takes part in Euro - Atlantic Partnership Council (EAPC). It is a framework of expanded political dimension and for closer military cooperation created by NATO Foreign Ministers in 1997. It replaced the North Atlantic Cooperation Council NACC. EAPC tasks are connected with consultations on specific security matters, e.g. crisis management, arms - control, defense policy planning and nuclear safety. Moreover, it brings 19 members of NATO and other 28 European countries, Finland among them, in closer relations on security issues.

The Finnish membership in NATO is an open issue, but public opinion is against it. Moreover, cooperation instead of membership seems to serve Finns best. "Close and constructive cooperation with the Alliance is high on the Finnish agenda. While such cooperation promotes European crisis management capabilities, it also enhances Finland's military interoperability and thus indirectly improves the country's security" 15 .

Finland had taken part in peace - keeping operations before 1990. However, Finns became more interested in this issue in the 90's. It forms a part of national security policy which assumes that every conflict in Europe could influence the situation of Finland. Finnish peacekeepers were

13 Ministry of Defense of Finland, Finnish Security and Defense Policy 2001, Section III: International Crisis Management, source: www.puolustusministerio.fi.

14 The Military Balance 1997/98, The International Institute for Strategic Studies, Oxford University Press, Oxford 1997, p. 30.

15 P. Sivonen, Finland and NATO, from: B. Huldt, T. Tiilikainen, T. Vaahtoranta, A. Helkama - RDgDrd, Finnish and Swedish Security. Comparing National Policies, Swedish National Defense College/Programme on the Northern Dimension of the CFSP/the Finnish Institute of Foreign Affairs, Helsinki-Stockholm 2001, p. 97. 
involved in three main European conflicts, namely in Bosnia (the NATO led IFOR/SFOR), Kosovo (the NATO - led KFOR) and the UN operations in Cyprus. It has to be emphasized that Finland began taking part in the NATO-led operations - it would have been impossible during the Cold War. In 1997 Finland occupied the sixth place among leading troop contributors -914 soldiers. According to the Finnish Peacekeeping Act the limit is 2000 soldiers $^{16}$.

The government presented a special report on security to Parliament in 1997. The report entitled "The European Security Development and Finnish Defense" concerned main changes in European political environment and underlined core bases of the Finnish position. "The basic components of Finland's security and defense policy can be presented as follows:

- Maintenance and development of a credible defense capability,

- Remaining militarily non - allied under the prevailing conditions,

- Participation in international cooperation to strengthen security"17.

The 'Nordic Balance of power' does not function any longer. The changes created convenient conditions for the development of Nordic cooperation on security issues. Security matters were discussed for the first time in the history of the Nordic Council in 1997. They had been formally banned before 1990. Nowadays Finland is interested in the development of the Nordic Coordinated Arrangement for Military Peace Support (NORDCAPS). The Memorandum was signed in Ĺlesund on 23 April 2002. The main aim of the project "is to adapt and develop Nordic co-operation within the area of military peace support operations, utilizing the proven ability of military interaction and enhancing the Nordic profile in such operations, in order to more beneficial efforts to support international peace and security"18. It would not be possible twelve years ago. Every attempt of closer cooperation between Finland and NATO member states, namely Denmark and Norway, was regarded as threat to Moscow. Nowadays Finland is much more interested in expanding the Northern Di-

16 The Military Balance 1997/98, The International Institute for Strategic Studies, Oxford University Press, Oxford 1997, p. 274.

17 Ministry of Defence of Finland, Introduction of the Report: Finnish Security and Defence Policy 2001; source: www.puolustusministerio.fi.

18 Forsvardepartementet, Memorandum of Understanding between the Ministry of Defense of the Kingdom of Denmark, the Ministry of the Republic of Finland, the Ministry of Defense of Norway, and the Government of the Kingdom of Sweden concerning Nordic Co-ordinated Arrangement for Military Peace Support (NORDCAPS), Ålesund, 23 April 2002. 
mension. Its attitude towards the Baltic States constitutes a part of the process.

On 21 November 2002 three Baltic States namely Estonia, Latvia and Lithuania were invited to join NATO. It has been an intention of Finland since these countries became independent. Before 1990 Finland could not interfere in internal relations within the Soviet Union and support them. In the 1990's the future of the Baltic States played a very important role in security policy of Finland. "The preservation of the Baltic States' independence and security is essential for stability and security in the region. These states should develop a territorial defense capability to raise the deterrence threshold against attack. This is of utmost importance, and fortunately the overall development is positive in this regard [...]. The Finnish President and Prime Minister have again and again in their public appearances stressed that the security interests of the three Baltic States should be taken into consideration as NATO decides upon its own development" $"$.

As far as the Finnish expenditures on defense are concerned, they have been decreasing since the 80's. In 1985 Finland allocated 2.8\% of its GDP to army. Accordingly, in $1995-2.3 \%, 1996-2.0 \%{ }^{20}$ and in $2002-$ $1.3 \%{ }^{21}$.

\section{The position of the Finish security policy in 2003:}

- Finland is not neutral anymore,

- Nonalignment,

- Pro - western orientation,

- No closer relation with Russia,

- Membership in the EU - participation in Common Foreign and Security Policy,

- Active participation in NATO - led operations,

- Participation in peace - keeping operations of the United Nations,

- Active support for the security of the Baltic States,

- Cooperation with other Nordic countries on security issues.

19 P. Sivonen, Finnish Security Policy and Baltic Security in the late 1990's, from: Baltic Security. Looking Towards the 21st Century, G. Arteus, A. Lejins (ed.), Latvian Institute of International Affairs and Försvarshögskolan, Riga 1997, p. 108.

20 The Military Balance 1997/98, The International Institute for Strategic Studies, Oxford University Press, Oxford 1997, p. 293.

21 The Ministry of Defense of Finland: www.puolustusministerio.fi. 


\section{Conclusions}

The Finnish security policy has faced crucial changes since 1990. Finland had to respond to all changes within its geopolitical environment. The change began with the collapse of the Soviet Union and the termination of the Warsaw Pact. It gave Finns new opportunities and a free hand in defining their own security policy.

At the global level Finland still participates in peacekeeping operations led by the United Nations. It became more active in the 1990's, e.g. the sixth contributor of troops in the world in 1997. Finland has still no chance to influence global security system in other way due to small population. This factor has been unchanged. At the moment it constitutes 'the third pillar' of the Finnish security.

Nonalignment remains a key feature of the Finnish policy. However, some scholars claim that Finland has been nonaligned de facto since 1990. It is a matter of a scientific discussion. The influence of the Soviet Union and existence of the Treaty of Friendship and Mutual Cooperation had been the main obstacles before. At the moment Finland is not a member of any military alliance and does not even apply for it.

The biggest changes were introduced after Finland had joined the European Union in 1995 - the first change - positive attitude towards EC/EU. The most important influence of membership was dropping neutrality the second change. First of all there was no necessity of maintaining it a real military threat disappeared, namely the Soviet Union. The second argument was that "after becoming a member of the EU Finland felt that it cannot be 'neutral', because the country is on the side of the EU. The concept of neutrality was replaced by "military nonalignment and an independent defense",22. The third - cooperation within European crisis management. The fourth - Finnish contribution to the Common Foreign and Security Policy, e.g. the Petersberg tasks or the Northern Dimension.

Another change, namely the third, can be observed within the Finnish attitude towards Russia. Until 1990 Finland was under persistent Soviet pressure. Every decision concerning security had to be consulted. After collapse of the Soviet Union, Finland has a freer hand in security policy.

The fourth change concerns the Finnish attitude towards NATO. It is obvious that these relations did not exist at all when Finland was domi-

22 Sweden to adopt new security policy doctrine - drops neutrality, from: Helsingin Sanomat, International Edition, 12 February 2002. 
nated by the Soviet Union. In case of war NATO could become an enemy and even attack targets on the Finnish territory. Nowadays Finland cooperates with the Atlantic Alliance on crisis management and peace-keeping issues. Moreover, Finland is a member of the Partnership for Peace program and Euro - Atlantic Partnership Council (EAPC). It has not become a member of NATO yet and does not even apply for such membership. Nevertheless, Finland supports other countries in the Baltic Sea region, namely the three Baltic States, in their attempts to become NATO's allies. Some scholars predict that Finland will join NATO in the nearest future, although there is no clear evidence bearing such claims. Anyway, the change appeared within the Finnish policy towards NATO.

The fifth change - the Nordic cooperation on security issues. It was impossible before 1990 due to so called 'the Nordic balance of power. At the moment Finland takes part in activity of the Nordic Council, the Nordic Council of Ministers and the Nordic Coordinated Arrangement for Military Peace Support (NORDCAPS).

The sixth change has occurred in attitude towards security of the Baltic States. Before 1990 these countries constituted parts of the Soviet Union. After becoming independent they began seeking the support of any bigger west - orientated country. Both Sweden and Finland help Estonia, Latvia and Lithuania, but the Finnish activity seems to be more convincing. Finland has encouraged NATO to adopt their applications for membership. This change means also that Finland has become the leader in this part of the Baltic Sea. Its security policy is more externally orientated and does not concern only the Finnish territory anymore.

To sum up, the Finnish security has faced a great change since 1990. One can observe significant changes within six of the eight chosen factors. They prove western orientation and a freer hand in activity.

Table

\begin{tabular}{||l|l|l|c||}
\hline \multicolumn{1}{||c|}{ The comparison of factors concerning the Finnish security policy in $\mathbf{1 9 9 0}$ and 2002} \\
\hline \multicolumn{1}{|c|}{$\mathbf{1 9 9 0}$} & \multicolumn{1}{|c|}{$\mathbf{2 0 0 2}$} & $\begin{array}{c}\text { '+' = change } \\
\text { '-' = no change }\end{array}$ \\
\hline $\begin{array}{l}\text { The UN peace-keeping } \\
\text { operations }\end{array}$ & Active participation & Active participation & - \\
\hline Neutrality & From 1935 & $\begin{array}{l}\text { Impossible to maintain } \\
\text { within the EU }\end{array}$ & + \\
\hline Nonalignment & $\begin{array}{l}\text { No membership in mi- } \\
\text { litary pacts }\end{array}$ & $\begin{array}{l}\text { No membership in mili- } \\
\text { tary pacts }\end{array}$ & - \\
\hline
\end{tabular}




\begin{tabular}{|l|l|l|c||}
\hline $\begin{array}{l}\text { Attitude towards the } \\
\text { EC/EU }\end{array}$ & $\begin{array}{l}\text { No membership, no co- } \\
\text { operation on security. }\end{array}$ & $\begin{array}{l}\text { A member - state from } \\
1995 ; \text { activity within the } \\
\text { CFSP, the Northern Di- } \\
\text { mension }\end{array}$ & + \\
\hline $\begin{array}{l}\text { Relations with the Soviet } \\
\text { Union/Russia }\end{array}$ & $\begin{array}{l}\text { Close relations, the mu- } \\
\text { tual treaty. }\end{array}$ & $\begin{array}{l}\text { Security policy comple- } \\
\text { tely independent from } \\
\text { Russia }\end{array}$ & + \\
\hline Attitude towards NATO & No relations & $\begin{array}{l}\text { Cooperation within the } \\
\text { PfP, EAPC, taking part } \\
\text { in NATO-led peace ke- } \\
\text { eping operations }\end{array}$ & + \\
\hline $\begin{array}{l}\text { Cooperation with Nor- } \\
\text { dic countries }\end{array}$ & $\begin{array}{l}\text { No cooperation on se- } \\
\text { curity issues due to 'the } \\
\text { Nordic Balance' }\end{array}$ & $\begin{array}{l}\text { Close cooperation, con- } \\
\text { sultations. The Nordic } \\
\text { Council } \\
\text { NORDCAPS }\end{array}$ & + \\
\hline $\begin{array}{l}\text { Finland and the Baltic } \\
\text { States }\end{array}$ & $\begin{array}{l}\text { The Baltic States wi- } \\
\text { thin the Soviet Union }\end{array}$ & $\begin{array}{l}\text { Intensive cooperation, } \\
\text { supporting their mem- } \\
\text { bership in NATO }\end{array}$ & + \\
\hline
\end{tabular}

\section{Abbreviations}

CFSP - Common Foreign and Security Policy

CSCE - Conference on Security and Cooperation in Europe (then OSCE)

EAPC - Euro-Atlantic Partnership Council

EC - European Community

EEC - European Economic Community

EU - European Union

IFOR - Implementation Force - Operation Joint Endeavour in Bosnia and Herzegovina

KFOR - Kosovo Force

NACC - North Atlantic Cooperation Council

NORDC - Nordic Coordinated Arrangement for Military Peace Support

APS

OSCE - Organization for Security and Cooperation in Europe

PfP - Partnership for Peace Program

SFOR - Stabilization Force in Bosnia and Herzegovina

UN - United Nations

WEU - Western European Union

WP - Warsaw Pact 


\section{Streszczenie}

Przedmiotem niniejszego artykułu jest porównanie polityki bezpieczeństwa Finlandii w przełomowym dla Europy roku 1990 oraz w roku 2002. Analizie poddano osiem czynników, na których podstawie można określić czy oraz jakim zmianom jakościowym uległa owa polityka. Są to: 1) relacje z EWG/UE, 2) stosunek wobec Paktu Północnoatlantyckiego, 3) udział w operacjach utrzymania pokoju, 4) relacje z ZSRR/Federacją Rosyjska, 5) współpraca z innymi państwami nordyckimi, 6) stosunki z państwami bałtyckimi powstałymi w wyniku rozpadu ZSRR, 7) polityka neutralności oraz 8) niezaangażowanie. Należy zaznaczyć, iż choć powyższy katalog jest zapewne niepełny, to obejmuje najważniejsze czynniki, jakie należy wziąć pod uwagę w przypadku Finlandii.

W pierwszej części przedstawiono tło historyczne oraz kształt fińskiej polityki bezpieczeństwa w 1990 roku, natomiast w drugiej - w 2002 roku. Wyniki, właściwe dla obu momentów, zostały porównane w podsumowaniu, celem ustalenia ilości oraz jakości zmian, które zaszły w ciagu dwunastu lat.

W obrębie sześciu spośród ośmiu wyżej wymienionych czynników odnotowano znaczące zmiany. Na ich podstawie można stwierdzić, iż polityka bezpieczeństwa Finlandii uległa przeorientowaniu z neutralnej w 1990 roku na wyraźnie prozachodnią w roku 2002. 